\title{
Effect of grater position on the size of grated sago (Metroxylon spp.)
}

\author{
${ }^{1,2}$ Wan Mohd Fariz, W.A., ${ }^{1,}$ Rosnah, S., ${ }^{2}$ Azman, H., ${ }^{2}$ Mohd Shahrir, A., ${ }^{2}$ Saiful Azwan, \\ A., ${ }^{2}$ Asnawi, S.H. and ${ }^{2}$ Zainun, M.S. \\ ${ }^{1}$ Department of Process and Food Engineering, Faculty of Engineering, Universiti Putra Malaysia, 43400, \\ UPM Serdang, Selangor, Malaysia. \\ ${ }^{2}$ Engineering Research Central, MARDI Headquarters, Persiaran MARDI-UPM, 43400, Serdang, Selangor, \\ Malaysia.
}

\begin{abstract}
Article history:
September 2018

Available Online: 6

November 2018

Keywords:

Sago,

Trunk,

Fiber orientation,

Grated size
\end{abstract}

Received: 21 June 2018

Received in revised form: 14

Accepted: 18 September 2018

DOI:

https://doi.org/10.26656/fr.2017.2(6).125

\begin{abstract}
The natural arrangement of sago palm's fiber orientation is parallel to the vertical axis of the trunk. Extraction of the sago starch requires breaking of the trunk into fine sizes. The sago size is affected by the grater position which affects the of starch recovery. This study was conducted to evaluate grating efficiency through sago size produced at the different direction of grating $\left(0^{\circ}\right.$ and $90^{\circ}$ to roller teeth rotation). Sago palm trunks without outer layer were cut into square blocks of $100 \mathrm{~mm}^{3}$. Each trunk block was placed on roller grater platform at a different position where the cutting spike was parallel to the vertical axis of sago trunk fiber orientation (grating at $0^{\circ}$ direction) and perpendicular (grating at $90^{\circ}$ direction). $100 \mathrm{~g}$ of dry grated sago was sifted to determine the size distribution with different sieve sizes i.e. $2.80 \mathrm{~mm}, 2.00 \mathrm{~mm}, 1.00 \mathrm{~mm}, 0.85 \mathrm{~mm}$ and $0.425 \mathrm{~mm}$. A total weight of $1 \mathrm{~kg}$ of grated sago was mixed with water and squeezed to be extracted. The starch recovery produced by the grating process at $0^{\circ}$ directions was $10.30 \%$ higher than $90^{\circ}$ directions. The present study showed that the direction of grating at $0^{\circ}$ was able to produce finer grated sago with maximum starch recovery.
\end{abstract}

\section{Introduction}

Sago (Metroxylon spp.) is one of the tropical trees that can grow in wet conditions including peat swamps (Jong, 1995a). In Sarawak, sago-based products such as 'kuih sagu mata ikan', sago cake, sago pudding and others are the traditional food consumed by the local people. The state has a wide area of swampy land which is suitable for the cultivation of sago palm. The sago industry in Sarawak, Malaysia is very well established, and it is one of the important industries that contributed to export the state revenue (Kamal et al., 2007; Karim et al., 2008). Based on a report by Malaysia Department of Statistic (2005), the export value was recorded about 45,300 metric tons of food grade sago starch that equivalent to RM 40.4 million. In 2015, about 184,163 metric tons of sago was production in Malaysia (DOA, 2015) and estimated to be equivalent to RM 164.2 million.

Based on a study by Vikineswary et al. (1994), $65.7 \%$ sago starch remained inside the grated trunk residue. Mostly, the trunk residue was widely dumped into the river. Referring to the Department of Statistic (2005), the export value of sago starch was 45,300 tonnes approximately equal to $34.3 \%$ of total sago production and the loss rate was estimated $65.7 \%$ which was equivalent to 86,770 metric tonnes of food grade sago starch or RM 61.3 million. While based on DOA (2015) report, 184,163 metric tons of sago was produced and the total loss rate was estimated equivalent to 352,755 metric tonnes. The loss was due to grater inefficiency during sago extraction process. One of the factors that affected the efficiency of starch extraction was depended on the proportion of starch cells that are ruptured during trunk grating process (Cecil, 1992). Therefore, the grater efficiency to produce finer grated sago is an important factor affecting sago starch recovery.

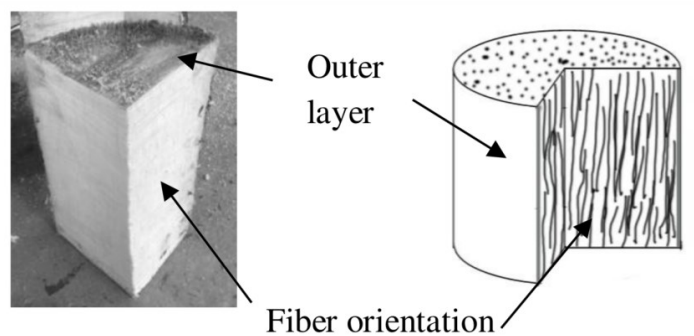

Figure 1. Sago trunk fiber orientation. 


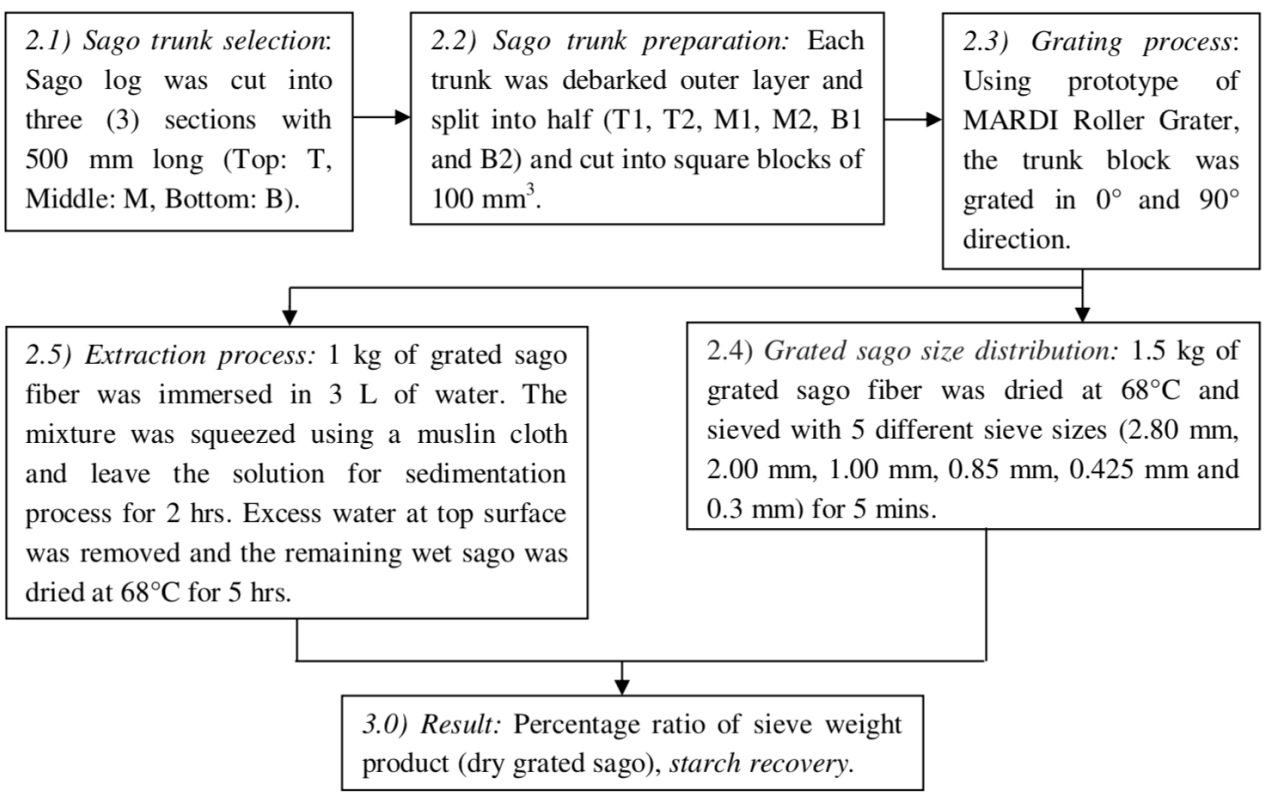

Figure 2. Flowchart of methodology

The grating efficiency depends on many factors such as the operation method or machine feeding handling. This study is aimed to determine the effect of difference sago trunk fiber orientation (Figure 1) during the grating process and to evaluate the starch and yield recovery during the extraction process.

\section{Materials and methods}

\subsection{Sago trunk selection}

Figure 2 shows the overview of methodology which includes sago trunk selection, sago trunk preparation, grating, extraction and grated sago size distribution. The selections of sago palm depend on the maturity of the trees which can produce maximum sago starch yield. According to a study by Jong (1995a), the maximum starch yield was reported found between growth and flowering stage. The sago palm material for this experiment was taken from Labu area (State of Negeri Sembilan).

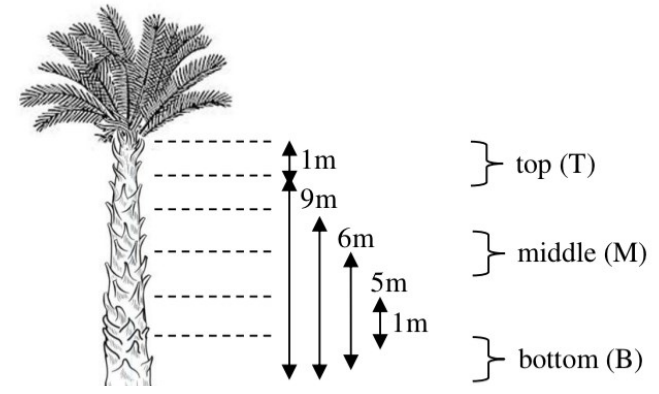

Figure 3. Sago palm trees section

The sago trees were divided into three parts: the top section (trunk section in between $1 \mathrm{~m}$ from the top leaf), the middle section (trunk section in between $5 \mathrm{~m}$ to $6 \mathrm{~m}$ from the ground) and the bottom section (trunks section between ground up to 1 meter) as shown in Figure 3. The sago trunks were cut into several parts in the length of
$500 \mathrm{~mm}$. Each selected trunk was marked as top (T), middle (M) and bottom (B) with permanent paint.

\subsection{Sago trunk preparation}

Each trunk's (T, M and B) outer layer were peeled off and then split into half section using handheld chainsaws (OG6816, Ogawa, Japan) as shown in Figure 4. Each half trunks section was marked as (T1 and T2) for top trunks section, (M1 and M2) for middle trunks section and (B1 and B2) for bottom trunks section. Then, each halved trunks section was cut into several square blocks of $100 \mathrm{~mm}^{3}$ and marked at the fibre orientation direction. The arrangement of sago palm's fiber orientation is parallel to the vertical axis of the trunk and used it as a reference for grating process.

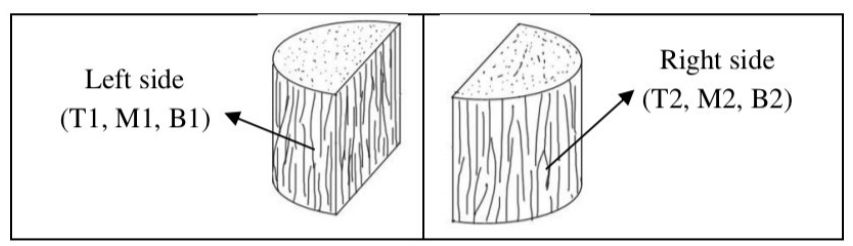

Figure 4. Half section of sago trunk

\subsection{Sago trunk grating process}

The grating process breaking the trunk structure into fine sizes. The grating process was done using a prototype of MARDI Roller Grater as shown in Figure 5. The trunk block T1 was placed on the platform whereby the position of the cutting spike was parallel to the vertical axis of sago trunk fiber orientation (Figure 6a) and then grated ( $\mathrm{T} 1$ trunks block known as $\mathrm{T} 0^{\circ}$ after grated). The process was repeated with trunk block M1 and $\mathrm{B} 1$ (known as $\mathrm{M} 0^{\circ}$ and $\mathrm{B} 0^{\circ}$ after grated). Next, the sago block T2 was placed on the platform with the position the cutting spike was perpendicular to the vertical axis of sago trunk fiber orientation (Figure 6b) 
and then grated (T2 trunks block known as $\mathrm{T} 90^{\circ}$ after grated). The process was repeated with sago trunk block $\mathrm{M} 1, \mathrm{M} 2, \mathrm{~B} 1$, and B2 (M1, M2, B1 and B2 known as $\mathrm{M} 0^{\circ}, \mathrm{M} 90^{\circ}, \mathrm{B} 0^{\circ}$ and $\mathrm{B} 90^{\circ}$ after grated). Each sample was collected separately.

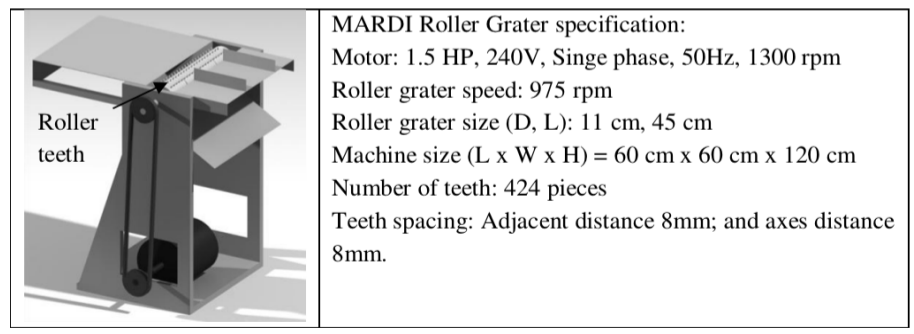

Figure 5. MARDI Roller Grater machine (specification)

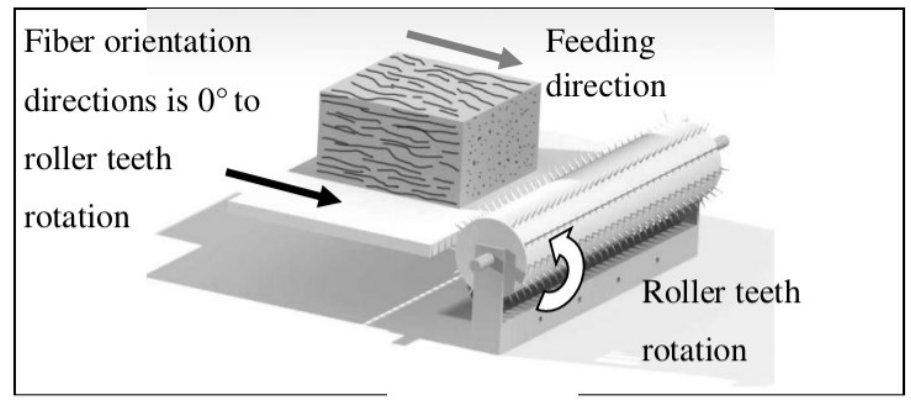

Figure 6a. Sago trunk block (T1, M1, B1) grating at direction $\left(0^{\circ}\right)$

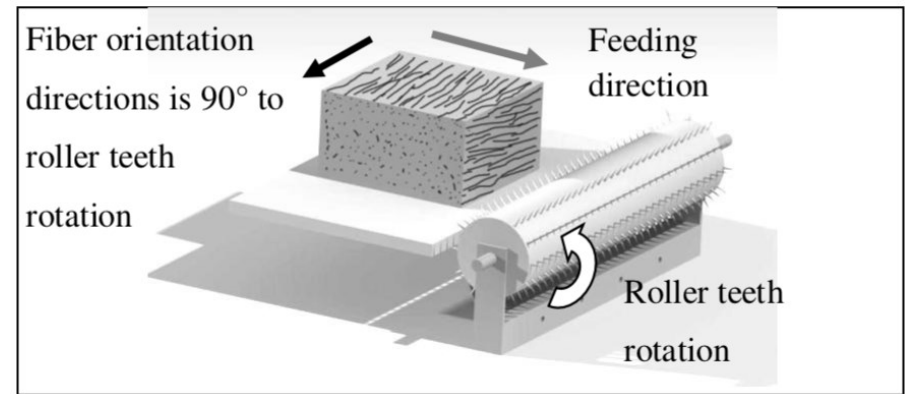

Figure 6b. Sago trunk block (T2, M2, B2) grating at direction $\left(90^{\circ}\right)$

\subsection{Grated sago size distribution}

The sieving process for dried grated sago fiber was to assess the particle size distribution. The initial moisture content of each grated sago fiber sample was recorded before the sieving process. The grated sago was dried using a drying oven (FAC-100, Protech, Malaysia). The oven temperature was set at $68^{\circ} \mathrm{C}$ (Jong,1995a). During the drying process, the moisture content of the sample was taken at every half an hour and the drying process was stopped when the readings didn't show any difference after 3 samples. After the drying process completed, the weight and moisture content of the sample was recorded. Each sample (weight of $100 \mathrm{~g}$ ) was sieved using a test sieve shaker (Endecott, United Kingdom). During the sieving process, at every 10 mins (ASTM Standards: C136-01) the weight of the sieve and the contents were taken, and the sieve process was stopped when the readings showed constant value after 3 readings. Based on the initial assessment, the dried grated sago particle size distribution was in the range of $0.25<\mathrm{X}<3.35$, where $\mathrm{X}$ value refers to sieve grade size. Therefore, the selected sieved grade sizes were $(2.80$ $\mathrm{mm}, 2.00 \mathrm{~mm}, 1.00 \mathrm{~mm}, 0.85 \mathrm{~mm}, 0.425 \mathrm{~mm}$ and 0.3 $\mathrm{mm})$. These procedures were repeated 3 times to get an average $(\mu)$ and standard deviation values using Equation 1 (Everitt, 1998). The final weight for each sieved product based on the sieve grade sizes was recorded. Then the percentage ratios (Equation 2) of weight for each sieve products were calculated where the percentage ratio referred to the percentage of the weight of the sieves products from the total weight of grated sago sample. The process was repeated once for all the sample of grated sago fiber $\left(\mathrm{T} 0^{\circ}, \mathrm{T} 90^{\circ}, \mathrm{M} 0^{\circ}, \mathrm{M}^{\circ} 0^{\circ}, \mathrm{B} 0^{\circ}\right.$ and $\left.\mathrm{B} 90^{\circ}\right)$.

$$
\begin{aligned}
& \text { Standard Deviation (SD) }=\sqrt{\frac{\sum(\mathrm{x}-\mu)^{2}}{\mathrm{n}-1}} \\
& \text { Weight percentage ratio }(\%)=\frac{\text { Weight of the sieves products }}{\text { Total weight of grated sago sample }} \times 100 \%
\end{aligned}
$$

\subsection{Extraction of grated trunk and starch recovery}

The extraction process is a process to extract the starch from the fiber. The starch recovery referred to the percentage of starch weight which has been extracted from the total weight of the grated sago. Based on the initial study, the volume of $1 \mathrm{~kg}$ of grated sago was equal to the volume of $3 \mathrm{~kg}$ of water. Therefore, $1 \mathrm{~kg}$ of grated sago fiber was mixed with $3 \mathrm{~L}$ of clean water to produce grated sago fiber slurry. The manual mixing was left for 5 mins to allow the water to seep into the grated sago fiber. Then, the material was squeezed manually using a muslin cloth until all the droplets were extracted out and the extracted liquids (mixture of starch slurry and excess water) were left for $2 \mathrm{hrs}$ for the sedimentation process inside the container. Next, the excess water on the top surface of the starch slurry was removed by tilting the container position and then the starch slurry was weighed. The moisture content of the starch slurry was recorded and then dried using a drying oven (FAC-100, Protech, Malaysia) at $68^{\circ} \mathrm{C}$ (Jong, 1995a). During the drying process, the moisture content of the sample was taken at every half an hour, and the drying process was stopped when the readings of the sample moisture content showed a constant value after 3 readings. Once completed, the weight of the sample (starch recovery) and moisture content were recorded. The process was repeated for all sample of grated sago fiber $\left(\mathrm{T}^{\circ}, \mathrm{T} 90^{\circ}\right.$, $\mathrm{M} 0^{\circ}, \mathrm{M} 90^{\circ}, \mathrm{B} 0^{\circ}$ and $\mathrm{B} 90^{\circ}$ ). The percentage of starch recovery was calculated (Equation 3) (Jong, 1995b; Kamal et al., 2007).

Starch Recovery $(\%)=\frac{\text { Weight of dry starch }}{\text { Total weight of fresh grated sago }} \times 100 \%$ 


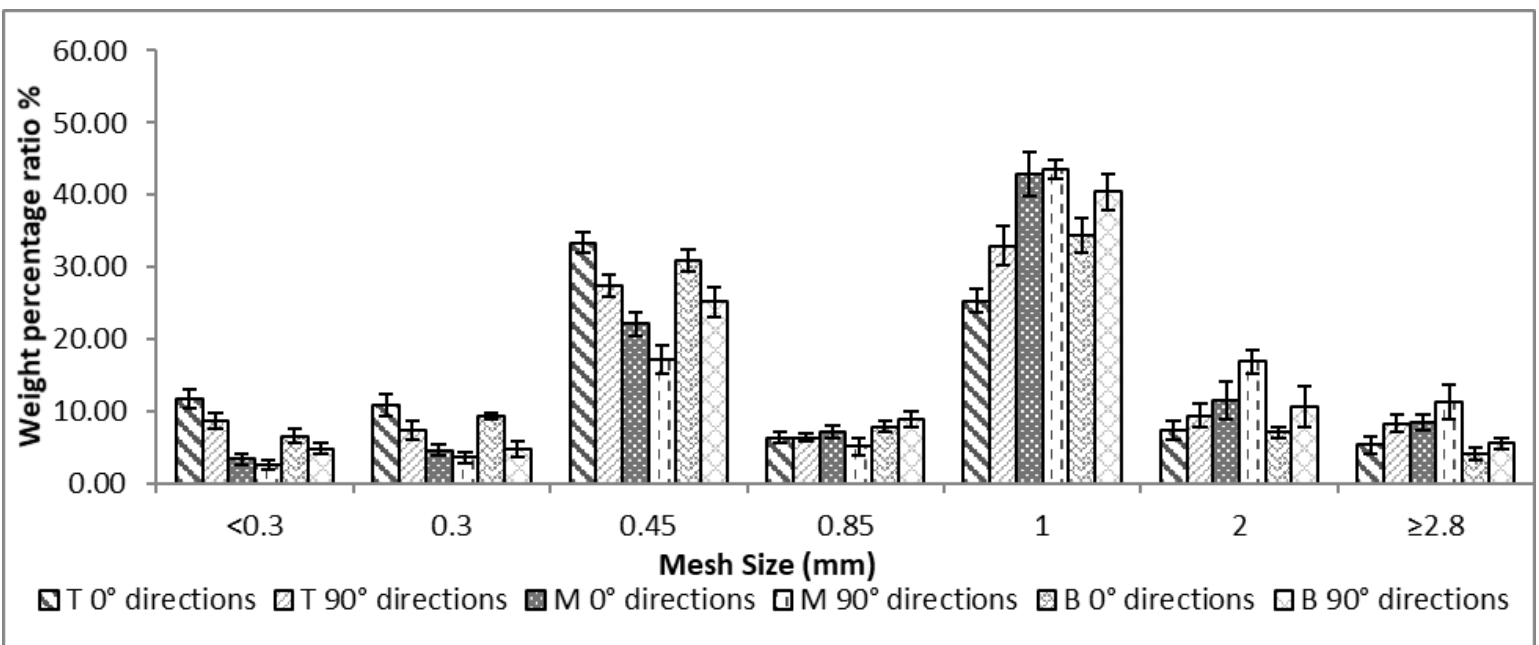

Figure 7. Weight percentage ratio (\%) of grated sago at different mesh size (mm). (T, M and B represent top, middle and bottom section of sago trunk)

\section{Results and discussion}

\subsection{Grated sago size distribution}

The particle size distribution determination was done at $5.15 \pm 0.37 \%$ average moisture content of grated sago after drying process from the initial average moisture content of $61.57 \pm 0.72 \%$. Figure 7 shows the weight percentage ratio (\%) of grated sago at different sieve mesh size $(\mathrm{mm})$. The value of $X<1 \mathrm{~mm}$ sieve mesh size referred to the finer grated sago and $X \geq 1 \mathrm{~mm}$ sieve mesh size refers to coarser or rougher grated sago. The error bars refer to the standard deviation value for average data of weight percentage ratio (\%). At the mesh size of $\mathrm{X}<0.3,0.3 \leq \mathrm{X}<0.45 \mathrm{~mm}, 0.85 \mathrm{~mm} \leq \mathrm{X}<1 \mathrm{~mm}$, $2 \leq \mathrm{X}<2.8$ and $\mathrm{X} \geq 2.8 \mathrm{~mm}$ the weight percentage ratio (\%) of grated sago at all section of sago trunks for both grating position of $0^{\circ}$ and $90^{\circ}$ was less than $17 \%$. The mesh size of $0.45 \mathrm{~mm} \leq \mathrm{X}<0.85 \mathrm{~mm}$ resulted with weight percentage ratio ranging from 17 to $33 \%$ (at all sections of sago trunk). The highest weight percentage ratio of dry grated sago produced at mesh size range of 1.00 $\mathrm{mm} \leq \mathrm{X}<2.00 \mathrm{~mm}$ with percentage ratio ranging from 25 to $44 \%$ (at all sections of sago trunk). Overall, the data show the capability of MARDI Roller Grater machine produce more grated sago at the size of $0.45 \leq \mathrm{X}<0.85$ and $1 \leq X<2 \mathrm{~mm}$. Up to date, no reported studies were available on the effect of mesh size on the weight percentage ratio of grated sago.

Figure 7 also shows that the total weight percentage ratio of dried grated sago (Equation 4) produced by a grating process with $0^{\circ}$ directions for mesh size range $\mathrm{X}<1 \mathrm{~mm}$ was $153.69 \%$. The value was higher than grating process at $90^{\circ}$ directions $(121.19 \%)$, with a percentage difference (Equation 5) of $21.15 \%$. However, at size range $X \geq 1 \mathrm{~mm}$ the grating process at $0^{\circ}$ directions, the total weight percentage ratio (Equation 6) was lower $(146.05 \%)$ than processing at $90^{\circ}$ directions (178.81\%) with a percentage difference value of $18.32 \%$ (Equation 5). This showed that grating process at $0^{\circ}$ directions produced finer grated sago than grating $90^{\circ}$ directions. Producing finer grated sago is important since it will produce more sago starch that can be dissolved from the grated sago during the extraction process (Colon and Anokke, 1986). Cecil (1992) added that the efficiency of starch extraction was depending on the proportion of starch cells that are ruptured during trunk grating process also. There were also other factors that affect the size of the sago grater produced such as grater teeth speed and arrangement as reported by Darma (2017). The present study used grater teeth speed and teeth spacing of $2250 \mathrm{rpm}$ and adjacent distance $40 \mathrm{~mm}$; axes distance $22 \mathrm{~mm}$ respectively (Darma et al., 2017).

$$
\begin{aligned}
& \sum_{x<1} W=\sum_{x<1} T W_{x}+\sum_{x<1} M W_{x}+\sum_{x<1} B W_{x} \\
& \frac{|\Delta V|}{\frac{\Sigma V}{2}} \times 100 \% \\
& \sum_{x \geq 1} W=\sum_{x \geq 1} T W_{x}+\sum_{x \geq 1} M W_{x}+\sum_{x \geq 1} B W_{x}
\end{aligned}
$$

Where $\mathrm{W}$ is weight percentage ratio (\%); $\mathrm{T}$ is trunk top section; $\mathrm{M}$ is trunk middle section; $\mathrm{B}$ is trunk bottom section; $X$ is the mesh size; $\mathrm{V}$ is the input value.

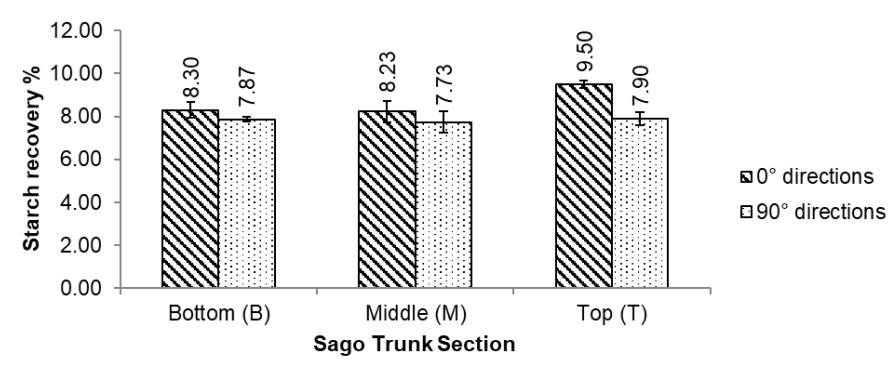

Figure 8. Starch recovery versus sago trunk section.

The total amount weight of starch that can be extracted from the $1 \mathrm{~kg}$ of grated sago sample was called as starch recovery. The average moisture content of starch slurry before drying process was $35.80 \pm 0.43 \%$ and after the drying process the moisture content value decreased to $10.33 \pm 0.55 \%$. The moisture content percentage reduction was $25.47 \%$. Figure 8 shows that at $0^{\circ}$ directions the starch recovery was higher than $90^{\circ}$ 
directions for all sago trunk sections. The top section of sago trunk resulted with the highest starch recovery, followed by the bottom and middle section. The starch recovery pattern distribution depends on palm trees maturity and it shows that the palm trees maturity was at stage 7 which was equal to 11.5 years old according to the starch distribution in the trunk as reported by Jong (1995b). The usage of immature sago palm (not reach full maturity stage) resulted with low starch recovery (Jong, 1995b). The total average starch recovery for all trunks section grated at $0^{\circ}$ and $90^{\circ}$ directions was $8.68 \pm 0.71 \mathrm{~g}$ and $7.83 \pm 0.09 \mathrm{~g}$ respectively. The percentage difference of total average starch recovery (Equation 7) at all trunk sections produced was $10.30 \%$ higher at $0^{\circ}$ directions as compared to $90^{\circ}$ directions. This proves that the grated sago produced from the grating process at $0^{\circ}$ directions was more efficient than $90^{\circ}$ directions during extraction process due to the effect of finer size of grated sago. Finer grated sago was more desirable as it resulted with higher starch recovery during extraction process (Cecil, 1992). Based on sago starch price reported by Malaysia Department of Statistic (2005) and starch recovery reported by Vikineswary et al. (1994), $10.30 \%$ of sago starch production in 2015 (DOA, 2015) at the weight of 55,302 metric tonnes which was equivalent to RM 49.3 million.

$$
\frac{|\Delta \mu V|}{\frac{\Sigma \mu V}{2}} \times 100 \%
$$

From Figure 8, the starch recovery percentage difference (Equation 7) produce by grated sago at $0^{\circ}$ directions and $90^{\circ}$ directions for the top, the middle and the bottom section trunk was $18.39 \%, 6.26 \%$ and $5.36 \%$ respectively. Based on the experimental results (Figure 8 ), about $7.73 \%$ to $9.5 \%$ of dry base starch recovery has been extracted from grated sago. The present result obtained on the dry base starch recovery was lowered as compared to the prior study by Kamal et al. (2007) with $25.76 \%$ recovery. The deviation might be due to the wet grading process before the extraction process. The starch granules present in the pith were dissolved in water and subsequently released when it was ruptured during the grinding process (Kamal et al., 2007).

Previously, the calculation of starch recovery mainly used wet base starch as an input. Therefore, for the current study, the value of starch recovery as wet basis (Equation 8) ranging from $10.80 \%$ up to $13.27 \%$ at moisture content of $35.80 \%$ (starch slurry before dried). The obtained value of the present study was in close agreement with Flach (1997) and Darma (2010) which obtained starch recovery ranges from 10 to $25 \%$ and 12.43 to $39.89 \%$, respectively. Meanwhile, Haryanto (1992), Cecil (1992), Yunus (1997) and Darma et al. (2017) resulted with the starch recovery of 15 to $25 \%, 23$ to $27 \%, 35.45 \%$ and 43 to $48 \%$ respectively. The variation of starch recovery obtained from this experiment with the reported studies by others might be due to the effect of the difference extraction method. The present study used squeezed grated sago method for extraction process which conducted without repetition to ensure optimal use of water and to produce good quality of sago. The conventional method of sago extraction involved with repetition of adding water to grated sago as extraction process of sago normally used a lot of water (Jong, 1995 A). Water addition during the extraction process was an important element since it helps to dissolve and release the sago starch granules (Kamal et al., 2007).

$$
\mathrm{M}_{\mathrm{n}}=\frac{\mathrm{w}_{\mathrm{w}}-\mathrm{w}_{\mathrm{d}}}{\mathrm{w}_{\mathrm{w}}} \times 100
$$

Where $\mathrm{M}_{\mathrm{n}}$ is a moisture content (\%) of material, $\mathrm{W}_{\mathrm{W}}$ is a wet weight of the sample, and $\mathrm{W}_{\mathrm{d}}$ is a weight of the sample after drying.

\section{Conclusion}

As a conclusion, the direction of the grating affected the grated sago size produced which is related to starch recovery. The grating process at $0^{\circ}$ directions was more efficient than $90^{\circ}$ directions in terms of producing finer grated sago and produced $10.30 \%$ higher of starch recovery during the extraction process. It was scientifically proven that finer grated sago produced higher sago starch recovery during the extraction process. It is recommended for the grating process at $0^{0}$ directions to ensure the maximum output starch recovery.

\section{Acknowledgment}

The authors would like to acknowledge the financial support by CRAUN Research Sdn Bhd and MARDI (Project code: FS024210). A special gratitude to MARDI team and Universiti Putra Malaysia facilities whose contribution in stimulating suggestions, encouragement and coordinate this project.

\section{References}

Bintoro, M.H. (2011). Progress of Sago Research in Indonesia. Proceeding of the 10th International Sago Symposium, 29-31 October 2011, p. 16-34. Bogor, Indonesia: IPB International Convention Center.

Cecil J. (2002). The development of technology for the extraction of sago. In Kainuma, K., Okazaki, M., Toyoda, Y. and Cecil, J.E. (Eds.). Proceedings of the International Symposium on Sago (Sago 2001)., p. 83-91. Tokyo, Japan: Universal Academy Press Inc.

Cecil J.E. (1992). Small-, Medium-, and Large-Scale 
Starch Processing (FAO Agriculture Services Bulletin) (No. 98). Rome: Food and Agriculture Organization of the United Nations.

Colon, F.J. and Annokke, G.J. (1986). Survey of some processing route of sago. In The development of the sago palm and its products. Report of the FAO/ BPPT consultation, Jakarta, Indonesia, 16-21 January 1984, p. 121-140. Rome: Food and Agriculture Organization of the United Nations.

Darma., Istalaksana, P. and Sarungallo, Z.L. (2010). Starch Content and production Potency of Natural Sago Palm (Metroxylon Sagu Rottb). Agrotek Journal 2(2), 7-14.

Darma., Santos, B. and Reniana (2017). Development of Cylinder Type Sago Rasping Machine Using Pointed Teeth. International Journal of Engineering and Technology, 17(1), 25-31.

Darma., Wang, X.L. and Kito, K. (2014). Development of Sago Starch Extractor with Stirrer Rotary Blade for Improving Extraction Performance. International Journal of Engineering and Technology (IJET), 6(5), 2472-2481.

DOA (2015). Malaysia Industrial Crops Statistics, Putrajaya: Department of Agriculture.

Everitt, B.S. (1998). The Cambridge Dictionary of Statistics. Cambridge, UK: Cambridge University Press.

Flach, M. (1983). The sago palm. FAO plant production and protection paper 47, AGPC/MISC/80. Rome, Italy: Food and Agriculture Organization of the United Nations.

Flach, M. (1997). Sago palm (Metroxylon sagu Rottb.), Rome: International Plant Genetic Resources Institute (IBPGR).

Haryanto, B. and Pangloli, P., (1992). Potency and Utilization of Sago Palm. Yogyakarta: Kanisius

Ishizuka, K., Hisajima, S. and Macer, D.R.J. (1995). Sago palm, a promising renewable carbohydrate resource: a material for global environmental conservation and sustainable development. Proceedings of the UNESCO 11-14 December 1995, p. 75-76. Japan: Tsukuba Science City.

Jong, F.S. (1995a). Distribution and Variation in the Starch Content of Sago Palms (Metroxylon sagu Rottb.) at Difference Growth Stages. Sago Palm, 3 (2), 45-54.

Jong, F.S. (1995b). Research for the development of sago palm (Metroxylon sagu Rottb.) cultivation in Sarawak, Malaysia. Wageningen, The Netherlands: Wageningen Agriculture University, $\mathrm{PhD}$ thesis.

Kamal, S.M.M., Mahmud, S.N., Hussain, S.A. and Ahmadun, F.R. (2007). Improvement on sago flour processing. International Journal of Engineering and Technology, 4(1), 8-14.

Karim, A.A., Tie, P.-L., Manan, D.M.A. and Zaidul, I.S.M. (2008). Starch from the Sago (Metroxylon sagu) Palm Tree-properties, Prospect, and Challenges as a new Industries Source for Food and Other Uses. Comprehensive Reviews in Food Science and Food Safety, 7(3), 215-228. https:// doi.org/10.1111/j.1541-4337.2008.00042.x

Malaysia Department of Statistic. (2005). Sarawak Export of Sago Starch, SITC Code: 592-150. Malaysia: Department of Statistic.

Oates C.G. and Hicks A. (2002). Sago starch production in Asia and the Pacific - problems and prospects. In Kainuma, K., Okazaki, M., Toyoda, Y. and Cecil, J.E. (Ed.). Proceedings of the International Symposium on Sago (Sago 2001), p. 27-36. Tokyo, Japan: Universal Academy Press Inc.

Singhal, R.S., Kennedy, J.F., Gopalakrishnan, S.M., Kaczmarek, A., Knill, C.J. and Akmar, P.F. (2008). Industrial production, processing, and utilization of sago palm-derived products. Carbohydrate Polymers, 72(1), 1-20. https://doi.org/10.1016/ j.carbpol.2007.07.043

Vikineswary, S., Shim, Y.L., Thambirajah, J.J. and Blakebrough, N. (1994). Possible microbial utilization of sago processing wastes. Resources, Conservation and Recycling, 11(1-4), 289-296. https://doi.org/10.1016/0921-3449(94)90096-5.

Yamamoto, Y. (2014). Sago as an Approach to Food and Nutritional Security. Global Food Security Forum, 7 -8 July 2014. Kuala Lumpur, Malaysia: Putrajaya Marriott Hotel.

Yunus, M.R. (1997). Improves V-tooth Blade Sago Grater. Magazine of Chemistry, No. 57, p. 1-4. Bogor: Indonesian Centre for Agricultural Library and Technology Dissemination (ICALTD) 